\title{
Conflicts of Religious Believes and Cultural Practices Among Muslims
}

\author{
Ibrahem Narongraksakhet \\ College of Islamic Studies \\ Prince of Songkla University \\ nibrahem@bunga.pn.psu.ac.th
}

\author{
Mohd Afandi Salleh \\ Faculty of Law and International Relations \\ Universiti Sultan Zainal Abidin, Malaysia \\ afandi@unisza.edu.my
}

\begin{abstract}
The conflicts and violence in southern Thailand provinces could be traced back in $19^{\text {th }}$ century and continue until today. The linkage between Islam and culture of the people in that provinces served as a means of defining the identity of the Malay-Muslims. The study contends that beside the main factors such as politics, and economy, the unrests in southern border provinces of Thailand were also rooted on religious beliefs and cultural practices among the Muslims. The frequency and intensity of conflicts varied with the extent to which the government sought to impose the wrong policy or alien norms which seemed against the religuious beliefs and cultural practices of the people in the southern provinces.
\end{abstract}

Keywords: Conflict; Religious Believes; Cultural Practices

\section{INTRODUCTION}

The frequency and intensity of conflicts varied with the extent to which the government sought to impose the wrong policy or alien norms in the region. The ultra-nationalistic policy of the Prime Minister Phibunsongkram followed by the assimilation policy used to cause bitter clashes and worsened the situation in southern border provinces of Thailand. It is estimated that during the period of 2004-2014 there were 6,286 casualties and 11,366 injuries occurred in the conflicts. In this paper, we contend that, the unrests in southern border provinces of Thailand, namely, Patani, Yala, Naratiwat and some parts of Songkhla provinces were rooted in few main factors such as politics and economy. However, for this study, we contend that religious beliefs and cultural practices could also be considered as among the factors that underpining the conflicts.

\section{RESEARCH METHODOLOGY}

This study used a qualitative descriptive. Data were collected by literature. Locus of research in the southern border provinces of Thailand, Pattani, Yala, Naratiwat and some parts of Songkhla province. This study examines the focus of religious beliefs and practices conflict between muslim culture.

\section{RESEARCH FINDINGS \& DISCUSSION}

Historical Perspectives of Southern Thailand: A Cultural Dimension. Southern Provinces of Thailand, namely, Pattani,
Yala, Narithiwat, Satun, and part of Songkla were part of an ancient Malay empire known as Langkasuka. Langkasuka which was founded as early as the first century, was an important regional port for Asian traders. Hinduism, Buddhism, and Islam were introduced to Langkasuka in the third, the eighth, and the tenth centuries, respectively. As Langkasuka gradually disappeared around the fourteenth and the early fifteenth centuries, the Kingdom of Pattani appeared as its replacement. Pattani became an important commercial center and served not only for Chinese, Siam, Malay and Indonesia traders, but also with European merchants.

The initial contact of Pattani with Islam was a by-product of Arab trade with China. Most historians generally agreed that that local Patani people, who were Malay converted to Islam during the thirteenth or fourteenth century and there are some sources argued that local inhabitants converted to Islam three hundred years before the court of Pattani embraced Islam and declared the kingdom an Islamic state in 1457 [1]. As Islam spread, it supplanted some of the people's old cultural observances, such as ceremonial practices and eating and clothing habits. The Jawi script of the Malay language replaced the Indian script, and liturgical Arabic entered the Malay language. The Islamization of Pattani also led to the emergence of a new sense of identity that helped to distinguish the Pattani Muslims from the non-Muslims. The prosperity and the population of the Kingdom of Pattani grew streadily and became the largest and most populous of the Malay states in the peninsula [2].

The Malays in Pattani mostly proud with the glorious past of the Kingdom of Pattani . They perceive the Southern part of Thailand as their ancestor land, and considered the Thais are the invaders and outsiders. Khun Den Tohmeena, a wellknown politician and a son of Hajji Sulong, noted that the "struggle" of the Malay-Muslims is not a new phenomenon. It is the struggle of the people of a land that used to prosper "as equal as those of Sri Ayuthaya Kingdom and Malacca Kingdom". Thus, they are resentful that some Thai bureaucrats in the southernmost provinces look down upon them and refer to the Malay-Muslims as immigrants or foreigner [3].

The linkage between Islam and Malay culture is that it serves as a means of defining the identity of the MalayMuslims whereby Islamic culture is embeded in their cultural practices or behaviors. For instance, Islam has supplanted a number of cultural practices, such as eating and clothing habits, social interaction between men and women, and 
ceremonial observances. The use of Jawi script is also another evidence of the direct effect of Islamic influence in the region. As a result, the influence of Islam has distinguished the Malays from the Thai in their socio-cultural realm. Consequently, the differences in culture between the Malay Pattani with Thai people created a division as the feeling of "we rather than they" existed in the province [4]. One of the problems Malay Pattani are facing is that the provincial government officials failed to understand or has a little knowledge on the religious belifes and culture of the Pattani people, hence it resulted that they could not obtain cooperation from the majority of Muslims. An example is the appointment of the provincial government officers has been done through the central government in Bangkok and mostly did not through the consent of the southern provinces people or their leaders. Some Malay-Muslims of southern Thailand, except for those in Satun, did not know Thai language and those who knew Thai sometime did not like to speak Thai.

This circumstance has been an obstacle to any meaningful communication between the State officials and the ethnic Malay-Muslims. Thus, the widespread use of Malay language constituted a major obstacle the State had to overcome. Moreover, this situation made the Thai bureaucrats with whom the Malays came into contact for official business appear to be outsiders living in the periphery of the Malays' world. Language is the most important aspects that directly contribute to the distrust of Malays toward the Thai authorities.

The importance of Malay language for the Malay-Muslims of southern provinces is twofold. It is the language of communication within households and the community and with their brethren across the border in Malaysia. Additionally, it is the language used for teaching Islam, especially in pondok. Most religious books that are written by Muslim scholars that are used in pondoks are written in Malay (Jawi) and Arabic. The Malay language is not only a part of the Malay-Muslim identity but also a part of their religion. This feeling is deeply embedded in the minds of MalayMuslims up to the present time; hence, the term "Islamic language" is used interchangeably with "Malay language". This connection between cultural practices especially the language makes Malays feel obliged to protect their language. Seemingly, the central government has currently paid less intention to the teaching Malays language until it has been related to the national security issues. The Thai authority has to consider the multicultural diversity of religion, cultural, and language identities

Religious Practices of Malay Pattani

Historically, Islam plays a crucial role in influencing the formation and the direction of views, actions, and goals of the people in southern Thailand. The desire to live according to what is prescribed in the Qur'an and Sunnah viz-a-viz to serve the will of Allah preoccupies the minds of many Malay Pattani Islam has been used as an ideological force to struggle against the central government of Thailand. Furthermore, the political culture of the Pattani community is influenced by the teaching Islam. Religious leaders are highly respected and regarded as the de facto leaders of the communities. They play a leading role in most community activities, ranging from prayers to festivals. They also act as the highest level of mediation within the community [5]. Religious leaders include members of the Provincial Council for Islamic Affairs, members of the Council for Mosques, and religious teachers.

The nature of Muslim society in the southern provinces is that of a close-knit community with much activity revolving around the mosques and pondok. The religious teachers play a role as religious educators at pondoks, mosques, and smaller prayer houses. Most of the traditional religious leaders acquire their knowledge through traditional religious education in local pondoks and mosques in Mecca, Saudi Arabia. They are considered as most authoritative source in matters concerning Islam and are the most influential and respected by majority of Muslim in this region. The Islamic private school teachers (ustaz) are mostly educated in formal Islamic schools and universities. Many are graduates of Middle East or North African universities. Considering from the number of supporters they are the second most respected and influential religious elite. Religious education is important in the Malay Pattani society. The roles of religious teachers as educators, together with other roles mentioned above have made them the most legitimate leaders in Patani society. They are the "informal leaders" that Thai government seeks to persuade to agree with the integration theur efforts [6].

Therefore, it is not suprising when the Thailand government tries to intervene the religious affairs and MalayMuslim religious leadership in southern border provinces, they faced a strong resistant from the local people of Pattani. For example, the central govenment policy is that the provincial Islamic councils has to be approved by the Ministry of Interior, the government has converted pondok into semi secular "private schools teaching Islam," and the state bureaucracy patronized religious affairs. This policy whereby the central government extended its political power that interfere with the religious affarirs, the protests and rebellions began among the locals. As observed by Pitsuwan, the former Minister of Foreign Affairs, that that policy has created a deeper sense of alienation of the Malay-Muslims from the state of Thailand. He argued that, the more the state imposed this policy, the more resistance it received from the MalayMuslim community [7].

\section{CONCLUSION}

Tensions and conflicts which led to the violence have multiple causes. There have been theories and assumptions trying to explain the conflict scenario. Each assumption and theory has their own logical explanations and supports. We contend that religions which constitute belief and culture is one of the factors that possibly contributed to the conflicts. The frequency and intensity of conflicts varied with the extent to which the government sought to impose the wrong policy or alien norms which seemed against the religuious beliefs and cultural practices of the people in the southern provinces. These continuous misguided policies imposed upon Muslims in the region had also intensified and accelerated the violence. Putting an end to the conflicts of the southern border 
provinces of Thailand is a task of the Government with the contributions of the local administrative council. However, failure to understand the religious issues and cultural aspect of the people in southern Thailand could endangered the relations between Buddhist majority and Muslim minority in southern Thailand.

\section{REFERENCES}

[1] Abdul Rahman Haji Abdullal. (2007). Sejarah dan Tamadun Islam. Alor star:Pustaka Darussalam.

[2] Nantawan Haemindra. (1976). "The Problem of Thai-Muslims in the Four Southern Provinces of Thailand," Journal of Southeast Asian Studies 7. 2 (September): 98-102.

[3] W.K. Che Man. (1990), Muslim Separatism: The Moros of Southern Philippines and the Malays of Southern Thailand (Quezon City: Ateneo de Manila University Press, p.38.

[4] Donald Tugby and Elise Tugby. (1989). "Malay-Muslim and ThaiBuddhist Relations in the Pattani Region: An Intepretation," in the Muslims of Thailand. Vol 2. ed. Andrew Forbes (Bihar, India: Center for Southeast Asian Studies) p. 77.

[5] Thomas M. Fraser, Rusembilan. (1960). A Malay Fishing Village. (New York: Conell University Press,), 164.

[6] Duncan McCargo. (2005). "Understanding Conflict in the Thai South Through Domestic Politics," Northern Illinois University, IL, 3- 6 April, 13-14

[7] Arong Suthasasna, (2000) “ Muslim Minority in the Context of Thai Politics," Warasan sangkhomsat ( Journal of Social Science, Chulalongkorn University), 31,1, July- December, p.82 